JFTH, Vol. 16, Issue 1 (2019)

ISSN: 2314-7024

E-ISSN: 2682-2180

\title{
High-Performance Work Practices, Creative Performance and Talent Retention in travel agents: The Mediation of Job Embeddedness
}

\author{
Heba Salah Zaki \\ Lecturer, Tourism Studies Department \\ Faculty of Tourism and Hotels, University of Sadat City, Egypt
}

\section{Bassam Samir Al-Romeedy \\ Lecturer, Tourism Studies Department \\ Faculty of Tourism and Hotels, University of Sadat City, Egypt}

\begin{abstract}
The aim of this research is to develop and investigate a model that examines the mediating role of job embeddedness in the relationships among high-performance work practices, creative performance and talented employee retention at Egyptian travel agents. Using a questionnaire, data were collected from 398 employees working at the Egyptian travel agents category A. To test the relationships among the study variables, the data were analyzed via LISREL 8.30 through structural equation modeling. The results revealed that the implementation of highperformance work practices (HPWPs) enhances job embeddedness (JE) of Egyptian travel agents' employees. JE, in return, leads to high levels of creative performance $(\mathrm{CP})$ and talented employee retention (TRT). The results also proved that JE partially mediate the relationships between HPWP, CP and TRT at the Egyptian travel agents.
\end{abstract}

Keywords: High-Performance Work Practices, Job Embeddedness, Creative Performance, Talented Retention, Egyptian Travel Agents.

\section{Introduction}

The literature frequently claims that the employees' turnover in the tourism and hospitality industry is constantly higher than in other industries, a matter that causes problematic managerial issue (Cho et al., 2006; Kim, 2014; Yam et al., 2018). In the past two decades, acquiring, developing and retaining talented staff have become one of the most significant aims of human resource management (HRM) practices (Wallis et al., 2004; Govaerts, et al., 2011; Pittino et al., 2016).Subsequently, each organization strives to retain their talented employees who have enough prior experience for as long as possible (Afsar et al., 2018). The research of Kim (2014) has identified several antecedents that lead to turnover intentions among travel agents' employees like: organizational, supervisor and coworkers support, personnel management, welfare, job stress, career advancement, compensation and external causes (e.g. company reputation and work environment). Therefore, under these circumstances, travel agents should find 
methods to create and maintain a work environment where there are a set of HRM practices, named as high-performance work practices (HPWPs) to encourage its employees doing their tasks effectively and increase employee retention. HPWPs refer to a set of coherent human resource practices (e.g. training, empowerment, rewards, work-family balance, employee selectivity, job security....) designed to enhance employee performance, attitude, motivation and commitment (Datta et al.,2005; Asmawi, \& Chew, 2017; Zhang et al., 2018). Indeed, recent researches show that HPWPs has influenced employee retention positively (e.g. Combs et al., 2006; kerr et al., 2007; Patel \& Conklin, 2012; Pittino et al., 2016).

As a critical strategy of employee retention, job embeddedness (JE) emerges to enable employers to retain such high-performance staff because it focuses on reasons why employees remain on their current jobs more than why they quit their jobs (Mitchell et al., 2001; Karatepe, 2013a). It is assumed that employees with such HPWPs appear to be more embedded in their jobs and are less likely to leave it (Karatepe \& Karadas, 2012; Afsar et al., 2018).

Moreover, based on the findings of earlier studies (e.g. Karatepe \& Vatankhah, 2014b; Athwaria, 2016; Tang et al., 2017), the implementation of HPWPs enhances the creative performance (CP) of employees. When employers give their employees values by empowerment, rewards, job security, and training, they are expected to appreciate this and in return reward their company by showing embeddedness behavior and performing their tasks effectively which leads to creativity and innovative behaviors in the organization (Athwaria, 2016). In short, when the organization implements HPWPs, employees become more embedded in their jobs, and likely to display creative performance and remain in their organizations. Accordingly, JE seems to mediate the impact of HPWPs on creative performance (CP) and the retention of talented employees (TRT).

With this realization, the current research aims at investigating the effects of eight key indicators of HPWPs (empowerment, training, rewards, job security, selection policies, teamwork, work-family balance, and career opportunities) on $\mathrm{CP}$ and the retention of talented employees via JE. Specifically, this research proposes and tests a research model that examines: (a) the effects of HPWPs on JE, CP and TRT; (b) the effect of JE on CP, and TRT; and (c) the mediating role of JE on the effects of HPWPs on CP and TRT.

The contributions of the current study cover a research gap in the existing tourism literature through the following five ways: First, as argued by Murphy et al. (2018), it is crucial to identify which HPWPs practices are more suitable for various tourism sectors, therefore, the current research will determine -for the first time- the most important practices for travel agents in Egypt. Second, the retention of talented employees who are able to generate new thoughts and behaviors (creative performance) in the service delivery process still in its infantile stage and little empirically researched (Karatepe \& Vatankhah, 2014b; Karatepe, 2016). This also valid for travel agents' employees who are expected to handle customer demands and complaints effectively. Thus, there is a need for more empirical studies regarding the factors that enhance $\mathrm{CP}$ of travel agents' employees. Considering this void in the current literature, this study examines the effects of HPWPs and JE on CP of travel agents' employees. Third, according to Robinson et al. (2014), job embeddedness is considered a critical factor to retain talented employees. Furthermore, Holtom et al. (2012) 
suggested that empirical studies should focus on the antecedents of JE rather than the consequences of it. Although this realization, empirical studies regarding factors fostering employees' job embeddedness are still scarce (Karatepe \& Karadas, 2012; Karatepe, 2013a, 2013c; Karatepe, 2016). Given this gap in the existing literature, this research evaluates the effects of HPWPs on job embeddedness of travel agents' employees. Four, there is a paucity of empirical research regarding the mediating mechanisms via which HPWPs affect performance outcomes (Karatepe \& Vatankhah, 2014b). The current research utilizes JE as a mediator in this relation because Wheeler et al. (2010) mentioned that researchers need to know more about JE as a main moderator variable. Besides, based on Karatepe (2013a) and Lee et al. (2014), JE is still require more empirical discussions as a mediating factor between HPWPs and behavioral outcomes. Five, almost all studies that examine the previous relationship in the tourism sector focused mainly on hospitality and airlines, while, there is no empirical study that examine this relationship in travel agents generally and particularly at Egyptian travel agents. Therefore, this study examines the Egyptian travel agents for testing the abovementioned relationships. Finally, the findings of this research will supply helpful implications for travel agents' managers relating to the acquisition and retention of talented employees who are likely to be creative.

\section{Theoretical background and hypotheses development}

\subsection{High-Performance Work Practices} (HPWPs)

HPWPs are defined as a bundle of internally coherent and consistent HRM practices designed to enhance employee performance, attitude, motivation, and commitment which enable any organization to acquire a sustainable competitive advantage(Datta et al.,2005; Asmawi, \& Chew, 2017; Zhang et al., 2018).Unfortunately, there is no full consensus among researchers regarding the practices that are considered HPWPs(Murphy et al., 2018).Combs et al. (2006) specified 13 practices that are mostly researched and accepted as HPWPs: incentive compensation; training; compensation level; participation; selectivity in staffing and recruitment; internal promotion; HR planning; performance assessment; teamwork; a system of grievous procedures; flexible work; information sharing and employment security. In the current study, the researchers selected the following eight practices as indicators of HPWPs: empowerment, training, rewards, career opportunities, job security, selection policies, work-family balance, and teamwork. These aforementioned practices have been proven to be among the most effective human resource practices and have been utilized in the previous HPWPs literature (e.g. Boselie et al., 2005; Zacharatos et al., 2005; Combs et al., 2006; Tang \& Tang, 2012; Karatepe, 2013a;Sofijanova \& Zabijakin-Chatleska, 2013; Karatepe et al., 2014; Zhanget al., 2018).

As argued by the studies of Boselie et al. (2005); Tang \& Tang (2012); Karatepe et al. (2013a) and (2014), training, empowerment and rewards are among the most influential HRM activities. The importance of these three practices is even more confirmed in-service sector such as hotels (Karatepe, 2013a; Karatepe et al. 2014) and airlines (Karatepe \& Vatankhah, 2014b). The more the employees have empowerment, the more they feel a freedom to handle customers' demands, expectations and complaints (Afsaret al., 2018). Employees also need to develop 
themselves, and training as one of HPWPs' indicators- can help them for reinforcing their knowledge, skills, and abilities, therefore they became able to perform their functions efficiently (Poulston, 2008). Regarding rewards, the presence of proper rewards in the workplace enhances individuals' feelings toward their company, because they realize that managers acknowledge and reward their efforts (Chiang \& Birtch, 2011). Job security is one of HPWPs dimensions that has been selected in this study because it remains a major problem in the travel and hospitality industry (Vatankhah, 2013). Job security promotes trust and confidence between employees and company, which in return encouraged employees to offer better performance outcomes (Davidson et al., 2011; Sofijanova \& Zabijakin-Chatleska, 2013).In the same context, Karatepe and Vatankhah (2014) stated that without offering job security flight attendants couldn't trust in the management of airline companies, which in turn makes it difficult for any company to retain talented employees. Similarly, the absence of job security in the hospitality industry affects the management's ability to hire and retain talented employees (Karatepe, 2013b). Teamwork has also been recommended as one of HPWPs practices in tourism studies like airlines (Karatepe \& Vatankhah, 2014b) and food and beverage industry(Sofijanova \& Zabijakin-Chatleska, 2013).Teamwork aimed at achieving tasks effectively through working with coworkers who havevarious skills and knowledge (Sofijanova \& Zabijakin-Chatleska, 2013). Effective teams can participate in the employees' career success (Kellett et al., 2009). Selective staffing process is also treated as an HPWPs indicator, which means thatthe employee selectivity and recruitment are according to strict preset criteria and procedures (Sofijanova \& Zabijakin-
Chatleska, 2013; Zhanget al., 2018). This process focuses on hiring the right individuals who fit well with the job requirements and work environment (Zacharatos et al., 2005). The existence of rigorous selective staffing policies enhances job performance level and reduce voluntary turnover (Vatankhah, 2013).

Work-family balance has been identified among efficient human resource practices (Karatepe et al. 2014; Zhang et al., 2018).According to Lin et al. (2013), employees in the tourism sector suffering from work overload and irregular working hours. Therefore, work-family conflict, work-leisure conflict, and work overload have been recognized among the major stressors for them (Karatepe, 2013c). The existence of workfamily balance in travel agents increase the employees' job embeddedness and reduce their turnover intentions (Khorakian et al., 2018). The last HPWPs indicator that has been represented in this research is Career opportunities, the availability of career opportunities encourages employees to stay in the organization and enhance their performance (Karatepe \& Vatankhah, 2014b). Once employees trust their future career development, their job attitudes become more positive (Liang \& Hsieh, 2005).Based on hospitality researches, the presence of career opportunities also enables managers to retain and attract talented employees (Karatepe, 2013b).In short, all of the previously mentioned HPWPs practices are considered important and listed in the hospitality and airlines industry (Tang \&Tang, 2012; Karatepe, 2013a; Sofijanova \& ZabijakinChatleska, 2013; Karatepe et al., 2014; Karatepe \& Vatankhah, 2014b). 


\subsection{Job Embeddedness (JE)}

$\mathrm{JE}$ is a relatively emerging construct in the current literature that represents the sum of forces motivating employees to stay in their current jobs(Mitchell et al., 2001; Nafei, 2014). Mitchell et al. (2001) determined links, fit and sacrifice as three dimensions of JE. Links refer to formal or informal ties among individuals or activities at the organization (e.g., the relationship with supervisor or coworkers) (Mitchell et al., 2001; Lee et al., 2014; Nicholas et al., 2016). While fit depicts the degree to which individuals' abilities, personal values and interests are compatible with organizational requirements and rewards (Mitchell et al., 2001; Ng \& Feldman, 2010; Lee et al., 2014). In short, fit refers to the employee's compatibility with his job settings and organizational culture (Karatepe, 2016; Nicholas et al., 2016). Finally, sacrifice means the ability of an employee to lose the job rewards and benefits that derived from working at the organization if he leaves it (Mitchell et al., 2001; Ng \& Feldman, 2010; Lee et al., 2014). It is worth mentioning that sacrifice refers to both material or psychological benefits (Mitchell et al., 2001).

According to Mitchell et al. (2001) and Lee et al. (2014), JE is categorized into two types: on-the-job embeddedness and off-the-job embeddedness. On-the-job embeddedness refers to the forces that keep individuals tied or immersed in their organizations, while off-theJE refers to forces that keep employees immersed in their communities and personal lives (Nafei, 2014).

\subsection{HPWPs and Job Embeddedness (JE)}

In a number of tourism and travel industry researches, the availability of HPWPs, as manifested by empowerment, training, rewards, job security, selection policies, teamwork, work-family balance, and career opportunities, makes employees embedded in their jobs(e.g. Karatepe \& Karadas, 2012; Karatepe, 2013a.;Vatankhah, 2013; Karatepe \& Vatankhah, 2014b; Afsar et al., 2018). The presence of HPWPs indicates that the organization management encourages and cares about the wellbeing of its employees, to embedded more in their work (Vatankhah, 2013; Afsar et al., 2018). According to Lee et al. (2014), higher job performance may provide greater rewards and availability of resources, which reciprocally leads to higher levels of job embeddedness. Again, when employers in the hospitality industry invest in HPWPs, employees find one way to reciprocate this by feeling a higher level of embeddedness in their work (Karatepe, 2013a; Afsar et al., 2018).Similarly, Karatepe and Karadas (2012) proved that training, empowerment, and rewards increased JE among frontline hotel employees in Romania. In airlines, Karatepe and Vatankhah (2014) revealed that flight attendants are embedded in their jobs in response to HPWPs provided by their company. More recently, Afsar et al. (2018) proved that HPWPs embedded the employees working in four and five-star hotels in their jobs. At Egyptian travel agents, it is expected that if employees are regularly trained to reinforce their knowledge, skills, and abilities, are empowered to handle customer demands and problems at once, have flexible work schedule, feel job stability and security, and are rewarded fairly, they will feel obliged to respond by showing high levels of JE. Accordingly, the following hypothesis is formulated:

\section{H1: HPWPs are significantly and positively related to JE.}




\subsection{HPWPs and Creative Performance (CP)}

Creative performance means the amount of new thoughts and behaviors created by employees in doing their job-related duties (Zhou \& Shalley, 2003; Wang \& Netemeyer, 2004). The implementation of HPWS means that the organizations invest in their employees, develop and value them which in return foster their creativity (Tang et al., 2017). The research of Mazzei et al. (2016) outlined and investigated the importance of nine HPWPs practices (e.g. job security, selective hiring, greater autonomy) for promoting employees' innovation in small and medium-size businesses. There is also an empirical evidence that HPWPs lead to influential and behavioral outcomes in different professions. In the tourism and hospitality industry, the results of Karatepe and Vatankhah (2014) show that the indicators of HPWPs have been positively affected the creative performance of flight attendants. In addition, the results of Karatepe et al. (2014) suggested that HPWPs influence creative performance of frontline employees in the four- and five-star hotels. Also, Chiang et al. (2015) found that HPWS trigger creative ideas and performance. Furthermore, the research of Athwaria (2016) revealed that the implementation of HPWPs enhances IT employee creativity and innovative behaviors. Athwaria (2016) added that when employers give their employees values by empowerment, rewards, and training, they appreciate this and reward their company by showing engagement behavior. These engaged employees -in response to HPWPs- become more motivated to perform well and do more than their tasks which lead to creativity and innovation in the organization. Furthermore, the study conducted by $\mathrm{Fu}$ et al. (2015) asserted that HPWPs had a positive effect on the innovation performance of employees in professional service organizations. Moreover, the study of Kang (2015) shows that HPWs were positively affected employees' creativity and organizational innovation performance in research and development (R\&D) units via innovative climate. More recently, Tang et al., (2017) proved that high-performance work system fosters employee creativity through enhancing perceived organizational support. Finally, according to Jeong and Shin (2017), HPWPs increase organizational creativity when the company subjected to organizational change. Accordingly, the following hypothesis is proposed:

H2: HPWPs are positively influence the creative performance of employees at the Egyptian travel agents.

\subsection{HPWPs and the retention of talented employees (TRT)}

According to Frank et al. (2004, p. 13), retention was defined as "the effort by an employer to keep desirable workers in order to meet business objectives". Almost all of the talent definitions supposed that talented people are those who have the main skills and abilities that allow them to work in a very effective way and differentiate them from other employees (Maślanka-Wieczorek, 2014). The retention of talented employees is considered one of the serious challenges that face many organizations (Wallis et al., 2004; Grobler \& Diedericks, 2009; Joy, 2016; Alferaih et al., 2018).Therefore, today, the war is for talent and the companies' orientation isto decrease turnover in favor of retaining talented staff (Wallis et al., 2004; Govaerts et al., 2011). Over the last twenty years, the researches of human resource management have focused primarily on the practices aiming at acquiring, developing and retaining talented workforces (Hiltrop, 1999; Govaerts et al., 2011). Since this period, the major concern of most 
researches have been focused not only on identifying the reasons of leaving organizations but also examining factors that motivate employees to stay (Moncarz et al., 2009), besides the benefits achieved as a result of retaining tenured employees (Ramlall, 2004). Indeed, tenured workforces not only save the costs of employees' separation, recruiting, selecting and hiring but also increase their productivity over time, which in turn lead to higher levels of competitiveness and profitability (Cho et al., 2006; Moncarz et al., 2009). In a number of various studies, HPWPs have been also identified among factors that positively influence employee retention (e.g. Combs et al., 2006; Pittino et al., 2016). Empirical results pointed out that the higher the number of HPWPs utilized, the more positive the employee attitudinal and behavioral responses (e.g. Macky \& Boxall, 2007; Pittino et al., 2016). Based on the empirical study of Combs et al. (2006), HPWPs considered an important antecedent of reducing turnover intention among frontline employees. According to scholars Kerr et al. (2007); Patel \& Conklin (2012) and Pittino et al., (2016), the adoption of HPWPs positively affected the retention of valuable employees in small and medium enterprises. Likewise, the studies by Cho et al. (2006); Moncarz et al. (2009) and Joy (2016) revealed that organizations that implement such HPWPs are more likely to face lower turnover rates. Specifically, Moncarz et al. (2009) revealed that hiring, promotions, training, employee recognition, rewards, and compensation positively influence employee retention. Furthermore, the research of Joy (2016) further found a strong negative relationship between high-performance work systems and the withdrawal behaviors of IT employees. Meanwhile, the results of Khan et al. (2011) find that the implementation of some HRM practices is positively affect both employee job satisfaction and retention.

Similarly, with regard to the tourism and hospitality context, a number of studies further proved that teamwork, career opportunities, selective staffing, and rewards were led to retain employees with high performance (e.g. Karatepe, 2013a; Vatankhah, 2013; Afsar et al., 2018). In Singapore airline, flight attendants who were satisfied with the application of different HR practices such as empowerment, teamwork, selective staffing, rewards, training, and retraining, stayed in their organization (Wirtz et al., 2008). Vatankhah, (2013) mentioned that having a number of HPWPs in the organization is beneficial for retaining talented staff and reducing turnover of flight attendants. The results of Afsar et al (2018) suggested that HPWPs reduce the turnover intention of frontline employees in four and five-star hotels, which positively impacts the actual voluntary turnover. When an organization's HPWPs aimed at empowering employees to carry out their responsibilities, providing professional training to update their skills, knowledge, and abilities and rewarding them fairly, in such circumstances, employees feel greater losses if they choose to leave the organization (Afsar et al., 2018). Similarly, Karatepe (2013a) proved that frontline employees with HPWPs were unlikely to show intentions to quit the organization. Therefore, the following hypothesis could be formulated:

\section{H3: The implementation of HPWPs at Egyptian travel agents is positively affect the retention of talented employees.}

\subsection{Job Embeddedness and Creative Performance (CP)}

As argued by various studies, job embeddedness has a positive effect on 
performance generally and creative performance particularly (Lee et al., 2004; Halbesleben \& Wheeler, 2008; Ng \& Feldman, 2010; Karatepe \& Karadas, 2012; Karatepe \& Vatankhah, 2014b; Karatepe 2016; Liu, 2018).Highly embedded employees are motivated to perform well because of three reasons: firstly, the positive feelings they have towards the work relationship (fit), secondly, the commitment they feel as a result of social ties (links) and thirdly, their powerful wish to retain their jobs and gain its rewards in the future (sacrifice) $(\mathrm{Ng} \&$ Feldman, 2010). Under these circumstances, Lee et al. (2004) show that employees who participated in a number of duties and are linked to people, fit well with their current jobs and organizational culture, and recognize that they will give up valued things as a result of voluntary turnover are motivated to perform well. Similarly, $\mathrm{Ng}$ and Feldman (2010) and Karatepe (2016) proved that job embeddedness enhances employees' motivation to generate, spread and implement innovative ideas for improving services at organizations. Specifically, Karatepe and Vatankhah (2014) proved that flight attendants with high JE offered high levels of creative performance. Furthermore, Halbesleben and Wheeler (2008) illustrated that job embeddedness is positively related to employee job performance and innovative behavior. More recently, Liu (2018) found that job embeddedness has positively affected employee performance. Accordingly, based on the previous discussion, the following hypothesis advanced:

H4: Job embeddedness positively affects the creative performance of Egyptian travel agents' employees.

\subsection{JE and the Retention of Talented Employees(TRT)}

According to Holtom and Inderrieden (2006), JE was also named as "the theory of staying". Holtom et al. (2006) have found that job embeddedness is a critical reason for employee retention than other best well-known factors such as commitment and job satisfaction. As depicted by Jiang et al. (2012), $\mathrm{JE}$ gives a strong theoretical basis that was designed to illustrate why staff stay at the company, incorporating the social, organizational, and perceptual motives that enhance employee retention. Results from a meta-analysis that has been conducted by Jiang et al. (2012) for JE in 65 scholarly literature showed that both on-the-job and offthe-job embeddedness impacted both intentions and actual turnover of employees, besides traditional reasons of rotation (job satisfaction and perceived alternative jobs). Meanwhile, Zhang et al. (2012) found that employees who are more embedded are more likely to remain in their current organizations compared to their less attached coworkers. According to Mitchell et al. (2001) and Lee et al. (2004) employees remain at the organization and don't leave it due to three reasons: firstly, when they have good contact or correlations with their coworkers and supervisors; secondly, when there is well fit between the employees' expectations and organizational culture and finally, they realize that they will lose benefits or opportunities provided by their current organization if they leave it. In the same context, Zhang (2013) says that links between colleagues, working partners and companies increase the employees' attachment and support them to keep the retention, as well as, the better the fit between the employee and his company, the higher the probability that he will remain in the organization. $\mathrm{He}$ added that employees 
don't leave the organization so as not to lose the benefits they get (Zhang, 2013). Sun et al. (2012) examined the mediating effect of employee's job embeddedness and outlined that the psychological capital positively influenced job performance and retention of staff who were more embedded in their works. Moreover, regression analyses in Young et. al. (2013) revealed that job embeddedness increases the employees' intention to remain in extension agents. The research of Ramesh and Gelfand (2010) also proved that teachers' job embeddedness (JE) is positively related to their retention. As JE level increased, teachers' intention to leave decreased. Recently, Watson (2018) proved that JE was shown as a predictor of retention among novice talent. Similarly, with regard to the tourism sector, the results of Nicholas et al. (2016) indicated that job embeddedness has a significant impact on turnover intentions of employees in the hotel industry. They added that employers and human resource managers should take the effect of JE into consideration when putting retention strategies. Similarly, the content analysis of the interviews in Yam et al. (2018) study referred that both community and job embeddedness might have a significant role in explaining employee's retention in a hospitality context. More recently, Khorakian et al. (2018) proved that JE was negatively affected the female's intention to leave work in travel agents. Similarly, Karatepe (2013a) and Afsar et al. (2018) found that embedded employees in four- and five-star hotels are unlikely to show turnover intentions. In airlines companies, Vatankhah (2013) proved that highly embedded flight attendants are more likely to stay in their companies. Therefore, as argued by prior empirical studies, JE reduces turnover and increases the retention of quality employees who already exist in the organization. Accordingly, the following hypothesis can be proposed:

\section{H5: JE enhances the retention of talented employees at Egyptian travel agents.}

\subsection{The mediating role of job embeddedness}

The current research develops and tests a conceptual model that explains JE as a mediator of the effects of HPWPs on CP and TRT. Prior empirical studies have discussed the mediating role of JE in illustrating the relationships among human resource practices, attitudinal and behavioral outcomes. For example, Harris et al. (2011) proposed a model to examine the mediating role of job embeddedness in the relationship between leader-member exchange (LMX) and workplace outcomes. The findings revealed that employees who have good relationships with their leaders or supervisors showed high $\mathrm{JE}$ and consequently were unlikely to quit the organization. Similarly, the study of Sun et al. (2012) detected that the level of employee's JE mediated the relationship between psychological capital and job performance. The research of Karatepe and Karadas (2012) that conducted on frontline hotel employees reported that job embeddedness functioned as a partial mediator of the effects of management commitment to service quality on service recovery performance. With a sample of 618 female employees working in travel agencies, Khorakian et al. (2018) proved that job embeddedness fully mediated the effects of work-leisure conflict, work-family conflict, and work overload on intention to quit.

In the same context and with regard to HPWPs, Karatepe (2013a)tested the mediating role of job embeddedness and investigated that JE fully mediates the impact of HPWPs and work social support on the intentions of frontline employees to leave the organization. In another study performed on 164 flight attendants in Iran, Karatepe and Vatankhah, (2014) proved that JE acted as a 
full mediator of the impacts of HPWPs on performance outcomes. Specifically, flight attendants with high-performance work practices were more embedded in their jobs, and therefore, this leads to high levels of creative performance and extra-role customer service (ERCS).Similarly, the results of Karatepe (2016) study also supported the model that examined the mediating role of job embeddedness on the association between coworker, family support and creative performance. In short, the existence of coworker and family support enhances employees' creative performance through JE. More recently, the research of Afsar et al (2018) reported that training, empowerment, and rewards as the indicators of HPWPs and trust in supervisor influenced the turnover intentions of frontline employees in the hospitality industry only through job embeddedness.

Prior empirical studies which searched job embeddedness informed that JE should be handled as a main mediating variable between organizational factors and job outcomes (Mitchell et al., 2001; Wheeler et al., 2010; Karatepe, 2013a).Besides, based on Karatepe (2013a) and Lee et al. (2014), JE still requires more empirical discussions as a mediating factor between HPWPs and behavioral outcomes. Hence, it is important to focus on expanding this relationship at the Egyptian travel agencies, to enhance the creative performance and talented employee retention at these agents. Consequently, the following hypotheses can be formulated:

H6. JE mediates the relationship between HPWPs and creative performance at the Egyptian travel agents.

H7. JE mediates the relationship between HPWP sand the retention of talented employees at the Egyptian travel agents.
The research conceptual framework and hypotheses are shown in Fig. 1.

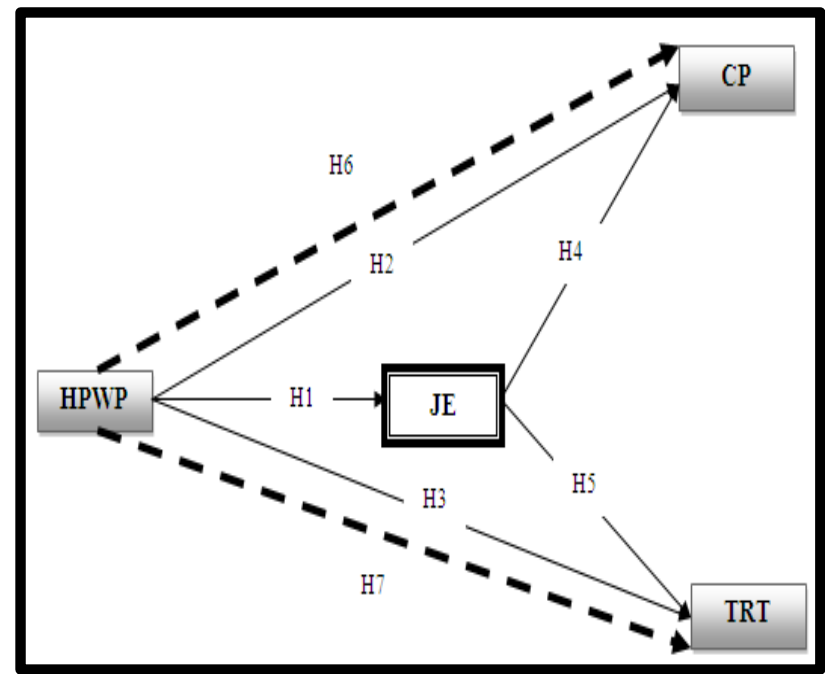

Figure 1. Theoretical framework and hypotheses

\section{Methodology}

\subsection{Measures}

A questionnaire was the study tool to collect data from respondents. It consisted of two sections, the first included four questions about respondents' demographic profile (Gender; Age; Education; Job experience), while the second section included four variables of the study High-Performance Work Practices(HPWPs), Job Embeddedness (JE), Creative Performance (CP), and Talent Retention (TRT). HPWPs were divided into eight dimensions measured by 39 items. Seven dimensions were derived from Karatepe and Vatankhah (2014) (empowerment (5 items); training (6 items); rewards (5 items); career opportunities (4 items); job security (4 items); selection policies (4 items); teamwork (5 items), while the eighth dimension (work-life balance) was measured by 6 items adopted from Carlson et al. (2009). Job Embeddedness (JE) was measured by 6 items adopted from Crossley et al. (2007). A 6 item scale from Wang and Netemeyer (2004) was used to measure the level of creative performance (CP). Finally, talent retention (TRT) was 
measured by 6 items developed by Humaid (2018). All the items in the second section were measured on a five-point Likert scale $(1=$ strongly disagree; $2=$ disagree; $3=$ neutral; $4=$ agree; $5=$ strongly agree).

\subsection{Sample and procedures}

Data for this study were collected from a randomly selected sample of 500 employees working in Egyptian travel agents (category A) in Cairo. Questionnaires were distributed during the period from November 2018 to January 2019. Only 432 questionnaires were returned, but 34 of them were incomplete and therefore discarded from the overall sample. Only 398 questionnaires were valid and had no missing data. The respondents were informed about the objective of this study. The questionnaires were distributed face-to-face and electronically by Google Drive. The respondents represented various jobs at the travel agents including tour leaders, tour operators, reservation agents, marketing agents, supervisors, religious tourism agents.

\section{Results}

\subsection{Demographic profile}

The results show that $68.1 \%$ of survey respondents were male. $38.4 \%$ of them were mostly 25-35 years old, followed by 36-45 years old (32.2). The majority of respondents had completed the university education with a percentage of $94.2 \%$. As for their work experience, $31.6 \%$ of respondents have work experience between 11-15 years, followed by those who have 5-10 years $(23.6 \%)$.

\subsection{Descriptive statistics}

Table 1: Means and standard deviation of constructs

\begin{tabular}{|c|c|c|c|}
\hline Variables and items & & Mean & SD \\
\hline $\begin{array}{c}\text { High-Performance Work } \\
\text { Practices }\end{array}$ & HPWP & 3.97 & 1.12 \\
\hline Empowerment (5 items) & EMP & 4.10 & .98 \\
\hline $\begin{array}{l}\text { I am empowered to solve } \\
\text { customer problems }\end{array}$ & EMP1 & 4.15 & .88 \\
\hline
\end{tabular}

\begin{tabular}{|c|c|c|c|}
\hline $\begin{array}{l}\text { I am encouraged to handle } \\
\text { customer problems by myself }\end{array}$ & EMP2 & 4.09 & 1.01 \\
\hline $\begin{array}{l}\text { I do not have to get chief } \\
\text { pursuer's approval before I } \\
\text { handle customer problems }\end{array}$ & EMP3 & 4.09 & 1.05 \\
\hline $\begin{array}{l}\text { I am allowed to do almost } \\
\text { anything to solve customer } \\
\text { problems }\end{array}$ & P4 & 4.01 & 1.06 \\
\hline $\begin{array}{l}\text { I have control over how I solve } \\
\text { customer problems }\end{array}$ & EMP5 & 4.11 & .99 \\
\hline Training (6 items) & TR & 3.93 & 1.15 \\
\hline $\begin{array}{l}\text { I receive continuous training to } \\
\text { provide a good service }\end{array}$ & TR1 & 3.91 & 1.26 \\
\hline $\begin{array}{l}\text { I received extensive customer } \\
\text { service training before I came } \\
\text { into contact with customers }\end{array}$ & TR2 & 4.04 & 1.05 \\
\hline $\begin{array}{l}\text { I receive training on how to } \\
\text { serve customers better }\end{array}$ & TR3 & 3.86 & 1.28 \\
\hline $\begin{array}{l}\text { I receive training on how to deal } \\
\text { with complaining customers }\end{array}$ & TR4 & 3.89 & 1.14 \\
\hline $\begin{array}{l}\text { I receive training on dealing } \\
\text { with customer problems }\end{array}$ & TR5 & 3.93 & 1.14 \\
\hline $\begin{array}{l}\text { I was trained to deal with } \\
\text { customer complaints }\end{array}$ & TR6 & 3.97 & 1.16 \\
\hline Rewards (5 items) & RW & & .43 \\
\hline $\begin{array}{l}\text { If I improve the level of service } \\
\text { I offer customers, I will be } \\
\text { rewarded }\end{array}$ & & 3.70 & 1.39 \\
\hline $\begin{array}{l}\text { The rewards I receive are based } \\
\text { on customer evaluations of } \\
\text { service }\end{array}$ & RW2 & 3.49 & 1.49 \\
\hline $\begin{array}{l}\text { I am rewarded for serving } \\
\text { customers well }\end{array}$ & RW3 & 3.58 & 1.41 \\
\hline $\begin{array}{l}\text { I am rewarded for dealing } \\
\text { effectively with customer } \\
\text { problems }\end{array}$ & & 3.45 & 1.50 \\
\hline $\begin{array}{l}\text { I am rewarded for satisfying } \\
\text { complaining customers }\end{array}$ & RW5 & 3.56 & 1.44 \\
\hline Career Opportunities (4 items) & $\mathrm{CO}$ & 4.01 & 1.19 \\
\hline $\begin{array}{l}\text { Employees have clear career } \\
\text { paths within the organization }\end{array}$ & $\mathrm{CO} 1$ & 4.02 & 1.24 \\
\hline $\begin{array}{l}\text { Employees have a good future } \\
\text { within this organization }\end{array}$ & $\mathrm{CO} 2$ & 4.07 & 1.14 \\
\hline $\begin{array}{l}\text { Employees' career aspirations } \\
\text { within this company are known } \\
\text { by their chief pursuers }\end{array}$ & $\mathrm{CO} 3$ & 3.93 & 1.25 \\
\hline $\begin{array}{l}\text { Employees who desire } \\
\text { promotion have more than one } \\
\text { potential position they could be } \\
\text { promoted to }\end{array}$ & $\mathrm{CO} 4$ & 4.00 & 1.20 \\
\hline Job Security (4 items) & JS & 3.81 & 1.28 \\
\hline
\end{tabular}




\begin{tabular}{|c|c|c|c|}
\hline $\begin{array}{l}\text { Employees can expect to stay in } \\
\text { the organization for as long as } \\
\text { they wish }\end{array}$ & JS1 & 3.80 & 1.30 \\
\hline $\begin{array}{l}\text { It is very difficult to dismiss an } \\
\text { employee in this organization }\end{array}$ & JS2 & 3.93 & 1.21 \\
\hline $\begin{array}{l}\text { Job security is almost } \\
\text { guaranteed to employees in this } \\
\text { organization }\end{array}$ & JS3 & 3.87 & 1.27 \\
\hline $\begin{array}{l}\text { If this company were facing } \\
\text { economic problems employees } \\
\text { in this organization would be } \\
\text { the last to get cut }\end{array}$ & JS4 & 3.63 & 1.41 \\
\hline Selection Policies (4 items) & SP & 4.10 & 1.07 \\
\hline $\begin{array}{l}\text { Great efforts are taken to select } \\
\text { the right person }\end{array}$ & SP1 & 4.16 & 1.00 \\
\hline $\begin{array}{l}\text { Long-term employee potential is } \\
\text { emphasized }\end{array}$ & SP2 & 4.13 & 1.03 \\
\hline $\begin{array}{l}\text { Considerable importance is } \\
\text { placed on the staffing process }\end{array}$ & SP3 & 4.06 & 1.19 \\
\hline $\begin{array}{l}\text { Very extensive efforts are made } \\
\text { in selection }\end{array}$ & SP4 & 4.03 & 1.14 \\
\hline Teamwork (5 items) & TW & 4.27 & .95 \\
\hline $\begin{array}{l}\text { Employees in my workgroup } \\
\text { work together effectively }\end{array}$ & TW1 & 4.35 & .90 \\
\hline $\begin{array}{l}\text { There is a strong team spirit in } \\
\text { my workgroup }\end{array}$ & TW2 & 4.26 & .97 \\
\hline $\begin{array}{l}\text { There is a lot of cooperation in } \\
\text { my workgroup }\end{array}$ & TW3 & 4.27 & 1.01 \\
\hline $\begin{array}{l}\text { Employees in my workgroup } \\
\text { are willing to put themselves } \\
\text { out for the sake of the group }\end{array}$ & TW4 & 4.23 & .98 \\
\hline $\begin{array}{l}\text { Employees in my workgroup } \\
\text { encourage each other to work as } \\
\text { a team }\end{array}$ & TW5 & 4.26 & .94 \\
\hline Work-Life Balance (6 items) & WLB & $\mathbf{3 . 9 5}$ & 1.17 \\
\hline $\begin{array}{l}\text { I am able to negotiate and } \\
\text { accomplish what is expected of } \\
\text { me at work and in my family }\end{array}$ & WLB1 & 3.97 & 1.24 \\
\hline $\begin{array}{l}\text { I do a good job of meeting the } \\
\text { expectations of critical people in } \\
\text { my work and family life }\end{array}$ & WLB2 & 4.03 & 1.22 \\
\hline $\begin{array}{l}\text { People who are close to me } \\
\text { would say that I do a good job } \\
\text { of balancing work and family }\end{array}$ & WLB3 & 3.93 & 1.02 \\
\hline $\begin{array}{l}\text { I am able to accomplish the } \\
\text { expectations that my } \\
\text { supervisors and my family have } \\
\text { for me }\end{array}$ & WLB4 & 4.05 & 1.07 \\
\hline $\begin{array}{l}\text { My co-workers and members of } \\
\text { my family would say that I am } \\
\text { meeting their expectations }\end{array}$ & WLB5 & 3.87 & 1.11 \\
\hline It is clear to me, based on & WLB6 & 3.82 & 1.14 \\
\hline
\end{tabular}

\begin{tabular}{|c|c|c|c|}
\hline $\begin{array}{l}\text { feedback from co-workers and } \\
\text { family members, that I am } \\
\text { accomplishing both my work } \\
\text { and family responsibilities }\end{array}$ & & & \\
\hline Job Embeddedness (6 items) & $\mathrm{JE}$ & 4.00 & 1.18 \\
\hline I feel attached to this company & JE1 & 3.98 & 1.24 \\
\hline $\begin{array}{l}\text { I am too caught up in this } \\
\text { company to leave }\end{array}$ & JE2 & 4.00 & 1.19 \\
\hline I feel tied to this company & JE3 & 4.01 & 1.21 \\
\hline $\begin{array}{l}\text { I simply could not leave the } \\
\text { company that I work for }\end{array}$ & JE4 & 3.96 & 1.24 \\
\hline $\begin{array}{l}\text { It would be difficult for me to } \\
\text { leave this company }\end{array}$ & JE5 & 4.04 & 1.13 \\
\hline $\begin{array}{l}\text { I am tightly connected to this } \\
\text { organization }\end{array}$ & JE6 & 4.03 & 1.16 \\
\hline $\begin{array}{c}\text { Creative Performance (6 } \\
\text { items) }\end{array}$ & $\mathbf{C P}$ & 4.30 & .90 \\
\hline $\begin{array}{l}\text { I carry out my routine tasks in } \\
\text { ways that are resourceful }\end{array}$ & $\mathrm{CP} 1$ & 4.38 & .79 \\
\hline $\begin{array}{l}\text { I come up with new ideas for } \\
\text { satisfying customer needs }\end{array}$ & $\mathrm{CP} 2$ & 4.33 & .86 \\
\hline $\begin{array}{l}\text { I generate and evaluate multiple } \\
\text { alternatives for novel customer } \\
\text { problems }\end{array}$ & CP3 & 4.27 & .93 \\
\hline $\begin{array}{l}\text { I have fresh perspectives on old } \\
\text { problems }\end{array}$ & CP4 & 4.28 & .95 \\
\hline $\begin{array}{l}\text { I improvise methods for solving } \\
\text { a problem when an answer is } \\
\text { not apparent }\end{array}$ & CP5 & 4.30 & .98 \\
\hline $\begin{array}{l}\text { I generate creative ideas for } \\
\text { service delivery }\end{array}$ & CP6 & 4.23 & .98 \\
\hline Talent Retention (6 items) & TRT & 4.12 & 1.11 \\
\hline $\begin{array}{l}\text { The organization can retain our } \\
\text { best performers. }\end{array}$ & TRT1 & 4.13 & 1.13 \\
\hline $\begin{array}{l}\text { Turnover is tracked across } \\
\text { divisions, locations, talent levels } \\
\text { and managers. }\end{array}$ & TRT2 & 4.12 & 1.09 \\
\hline $\begin{array}{l}\text { The reasons people leave, } \\
\text { especially top performers, are } \\
\text { recorded and addressed }\end{array}$ & TRT3 & 4.17 & 1.10 \\
\hline $\begin{array}{l}\text { Creating a culture that makes } \\
\text { employees want to stay with the } \\
\text { organization. }\end{array}$ & TRT4 & 4.12 & 1.12 \\
\hline $\begin{array}{l}\text { Top performers are challenged } \\
\text { to improve their skills }\end{array}$ & TRT5 & 4.08 & 1.14 \\
\hline $\begin{array}{l}\text { I am able to balance work } \\
\text { priorities with my personal life }\end{array}$ & TRT6 & 4.10 & 1.12 \\
\hline
\end{tabular}

Table (1) indicates the means and standard deviations (SD) for each item and overall variables. Regarding high-performance work practices (HPWPs) as an independent variable, 
the mean was 3.97, and SD was 1.12. As for practices of (HPWPs), teamwork was the highest with a mean of 4.27 , followed by selection policies (4.10), then empowerment (4.09), then career opportunities (4.01), then work-life balance (3.95), training (3.93), followed by job security (3.81), and finally comes reward as the lowest practice (3.56). The result also shows that the mean of Job embeddedness (JE) as mediating variables was 4.00 and SD was 1.18. Moreover, the means of the two dependent variables, creative performance $(\mathrm{CP})$ and talent retention (TRT) were 4.30 and 4.12 respectively, and SD were 0.90 and 1.11 respectively.

\section{Measurement model}

The study tested the validity and reliability of all scales. Composite reliability and Cronbach's alpha were used to test the reliability. AVE (Average Variance Extracted) was used to test the convergent validity. Table (2) indicates that all values of composite reliability and Cronbach's alpha were higher than the minimum limit of $70 \%$ according to Hair et al. (1992). The same table also shows that the value of AVE was more than 0.69 which is higher than the minimum value of convergent validity ( 0.5 or higher) according to hair et al. (2014).

Table 2: Composite reliability, Cronbach's Alpha, AVE and VIF

\begin{tabular}{|l|c|c|c|}
\hline \multicolumn{1}{|c|}{ Constructs } & $\begin{array}{c}\text { Composite } \\
\text { reliability }\end{array}$ & $\begin{array}{c}\text { Cronbach's } \\
\text { Alpha }\end{array}$ & AVE \\
\hline HPWPs & 0.799 & 0.796 & 0.699 \\
\hline JE & 0.841 & 0.844 & 0.749 \\
\hline CP & 0.911 & 0.909 & 0.714 \\
\hline TRT & 0.864 & 0.862 & 0.755 \\
\hline
\end{tabular}

HPWPS: High-Performance Work Practices; JE: Job Embeddedness; CP: Creative Performance; TRT: Talent Retention.

\subsection{Structural model testing}

The square roots of AVE for discriminate validity were tested to assess the variables validity. According to Hair et al. (2014), the square roots of AVE should be higher than the correlation between a pair of variables, as shown in bold type along the diagonal in table (3). For example, the correlation between JE and $\mathrm{CP}$ was .711, which is less than the respective AVE of JE (.874) and CP (.903). Table (3) also depicts that the square roots of AVE for all the variables are greater than the highest correlations with any other variables.

Table 3: Squared roots of AVE

\begin{tabular}{|l|l|l|l|l|}
\hline & HPWPS & JE & CP & TRT \\
\hline HPWPS & $\mathbf{0 . 8 7 1}$ & & & \\
\hline JE & 0.759 & $\mathbf{0 . 8 7 4}$ & & \\
\hline CP & 0.819 & 0.711 & $\mathbf{0 . 9 0 3}$ & \\
\hline TRT & 0.787 & 0.687 & 0.703 & $\mathbf{0 . 8 9 3}$ \\
\hline
\end{tabular}

Bold values indicate the square roots of AVE

HPWPS: High-Performance Work Practices; JE: Job Embeddedness; CP: Creative Performance; TRT: Talent Retention.

\subsection{Model fit}

Table (4) indicates the suggested ranges of some model fit indicators.

Table 4: ranges of model fit indicators

\begin{tabular}{|c|c|c|}
\hline Indicators & Ranges & Recommended by \\
\hline$X^{2} / d f$ & $1-3$ & Gefer et al., 2000 \\
\hline $\begin{array}{l}\text { Goodness of fit index } \\
\text { (GFI) }\end{array}$ & $\begin{array}{c}\text { More } \\
\text { than } .90\end{array}$ & Chan et al., 2007 \\
\hline Normed fit index (NFI) & $\begin{array}{l}\text { More } \\
\text { than } .90\end{array}$ & $\begin{array}{l}\text { Tabachnick and } \\
\text { Fidell, } 2001\end{array}$ \\
\hline $\begin{array}{l}\text { Comparative fit index } \\
(\mathrm{CFI})\end{array}$ & $\begin{array}{l}\text { More } \\
\text { than } .95\end{array}$ & $\begin{array}{l}\text { Schumacker and } \\
\text { Lomax, } 2010\end{array}$ \\
\hline $\begin{array}{l}\text { Tucker - Lewis index } \\
(\mathrm{TLI})\end{array}$ & $\begin{array}{c}\text { More } \\
\text { than } .95\end{array}$ & $\begin{array}{l}\text { Hu and Bentler, } \\
1999\end{array}$ \\
\hline $\begin{array}{l}\text { Root Mean Square } \\
\text { Error of Approximation } \\
\text { (RMSEA) }\end{array}$ & $.05-.08$ & Hair et al., 2010 \\
\hline \multicolumn{3}{|c|}{$\begin{array}{l}\text { According to the above ranges of model fit } \\
\text { indicators, table }(5) \text { shows that } X^{2} / d f=2.021 \text {, } \\
\text { GFI }=.911, \mathrm{CFI}=.967, \mathrm{NFI}=.915, \mathrm{TLI}=.961 \text {, }\end{array}$} \\
\hline
\end{tabular}


and $\mathrm{RMSEA}=.032$. all these values fell within the recommended ranges in table (5).

Table 5: Model fit summary for the research model

\begin{tabular}{|l|c|}
\hline \multicolumn{1}{|c|}{ Fit index } & Model \\
\hline$X^{2}$ & 671.028 \\
\hline Df & 332 \\
\hline $\mathrm{P}$ & 0.000 \\
\hline$X^{2} / d f$ & 2.021 \\
\hline Goodness-of-fit index (GFI) & 0.911 \\
\hline Comparative fit index (CFI) & 0.967 \\
\hline Normed Fit Index (NFI) & 0.915 \\
\hline Tucker-Lewis index (TLI) & 0.961 \\
\hline RMSEA & 0.032 \\
\hline
\end{tabular}

Table (6) indicates the path coefficients $(\beta)$, CR (Critical Ratio), and the Sig. of the model. The table shows that the HPWPs (independent variable) significantly and positively affect job embeddedness (mediator), creative performance and talent retention(dependent variables).

Table 6: path coefficient, CR, and Sig.

\begin{tabular}{|l|c|c|c|}
\hline \multicolumn{1}{|c|}{ Path } & Path Coefficient & CR & Sig. \\
\hline HPWPS $\rightarrow$ JE & 0.816 & 13.512 & 0.000 \\
\hline HPWPS $\rightarrow$ CP & 0.837 & 11.871 & 0.000 \\
\hline HPWPS $\rightarrow$ TRT & 0.723 & 8.795 & 0.000 \\
\hline JE $\rightarrow$ CP & 0.711 & 7.794 & 0.000 \\
\hline JE $\rightarrow$ TRT & 0.703 & 12.853 & 0.000 \\
\hline
\end{tabular}

HPWPS: High-Performance Work Practices; JE: Job Embeddedness; CP: Creative Performance; TRT: Talent Retention.

Fig. (2) indicates the path coefficients $(\beta)$, the $P$ value, and the variance explained by the model for all variables.

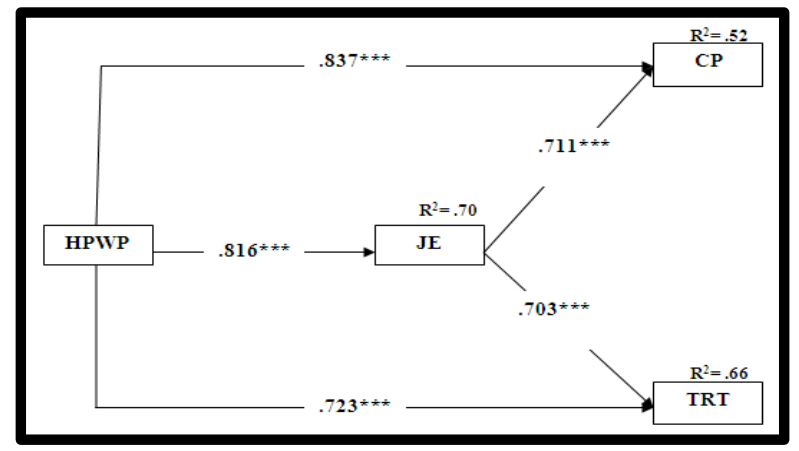

HPWPS: High-Performance Work Practices; JE: Job Embeddedness; CP: Creative Performance; TRT: Talent Retention.

Figure 2. Path coefficients, and P-values, and $\mathrm{R}^{2}$
Fig. (2) depicts that HPWPs have a significant and positive influence on $\mathrm{JE}\left(\beta=.816^{* * *}\right)$. Additionally, HPWPs have a significant and positive impact on both $\mathrm{CP}$ and TRT $(\beta=$ $.837 * * * ; \beta=.723 * * *$ respectively). Hence, $\mathrm{H} 1$, $\mathrm{H} 2$, and $\mathrm{H} 3$ are all accepted. Moreover, JE also has a significant and positive effect on both $\mathrm{CP}$ and TRT $\left(\beta=.711^{* * *} ; \beta=.703^{* * *}\right.$ respectively). Consequently, $\mathrm{H} 4$ and $\mathrm{H} 5$ are accepted. Also, Fig. (2) indicates that HPWPs explain the variance in JE by $70 \%$. while HPWPs explain the variance in CP and TRT by $52 \%$ and $66 \%$ respectively.

To know if the mediator variable plays a full or partial role in the relationship between the independent and dependent variables;

If the indirect relationship between the independent variable and the dependent variable is significant, there is a mediating role for the mediator variable.

If the indirect relationship between the independent variable and the dependent variable is insignificant, there is no mediating role for the mediator variable.

If the direct relationship between the independent variable and the dependent variable is significant, there is a partial mediating role for the mediator variable.

If the direct relationship between the independent variable and the dependent variable is insignificant, there is a full mediating role for the mediator variable.

According to the above four conditions, table (7) shows that job embeddedness plays a partially mediating role in the relationship between HPWPs, Creative Performance (CP) and talent Retention (TRT) because of the significance of the direct and indirect relationship between HPWPs, CP and TRT. Therefore, $\mathrm{H} 6$ and $\mathrm{H} 7$ are accepted. Additionally, table (7) revealed that HPWPs and JE explain the variance in CP by $69 \%$, and by $74 \%$ in TRT. These results confirm the 
mediating role of $\mathrm{JE}$ in the relationship between HPWPs, CP and TRT.

Table 7: Indirect effect results

\begin{tabular}{|c|c|c|c|c|c|}
\hline \multirow{3}{*}{ Path } & \multicolumn{2}{|c|}{ Effect } & \multicolumn{2}{|c|}{ Significance } & \multirow[b]{2}{*}{ Outcome } \\
\hline & $\begin{array}{l}\text { Direct } \\
\text { effect* }\end{array}$ & $\begin{array}{l}\text { Indirect } \\
\text { effect** }\end{array}$ & Direct & Indirect & \\
\hline & \multicolumn{5}{|c|}{ Via JE } \\
\hline \multirow[t]{2}{*}{$\begin{array}{c}\text { HPWPs } \\
\rightarrow \mathrm{CP}\end{array}$} & .52 & .69 & $\mathrm{P}=.019$ & $\mathrm{P}=.029$ & $\begin{array}{c}\text { Partial } \\
\text { mediation } \\
\text { at } 5 \%\end{array}$ \\
\hline & \multicolumn{5}{|c|}{ Via JE } \\
\hline $\begin{array}{l}\text { HPWPs } \\
\rightarrow \text { TRT }\end{array}$ & .66 & .74 & $\mathrm{P}=.040$ & $\mathrm{P}=.033$ & $\begin{array}{c}\text { Partial } \\
\text { mediation } \\
\text { at } 5 \%\end{array}$ \\
\hline
\end{tabular}

* Direct effect means the effect of independent variables (HPWPS) on dependent variable (CP or TRT) without the existence of mediator variable (JE).

** Indirect effect means the effect of independent variables (HPWPS) on dependent variable (CP or TRT) in the existence of mediator variable (JE).

Based on the above results, table (8) summarizes the test of hypothesis in this study.

Table 8: Summary of hypothesis testing

\begin{tabular}{|l|c|}
\hline Hypothesis & Test \\
\hline $\begin{array}{l}\text { Hypothesis 1: HPWPs are significantly and } \\
\text { positively related to JE. }\end{array}$ & Accepted \\
\hline $\begin{array}{l}\text { Hypothesis 2: HPWPs are positively } \\
\text { influence the creative performance of } \\
\text { employees at the Egyptian travel agents. }\end{array}$ & Accepted \\
\hline $\begin{array}{l}\text { Hypothesis 3: The implementation of } \\
\text { HPWPs at Egyptian travel agents is } \\
\text { positively affect the retention of talented } \\
\text { employees. }\end{array}$ & Accepted \\
\hline $\begin{array}{l}\text { Hypothesis 4: Job embeddedness positively } \\
\text { affects the creative performance of Egyptian } \\
\text { travel agents' employees. }\end{array}$ & Accepted \\
\hline $\begin{array}{l}\text { Hypothesis 5: JE enhances the retention of } \\
\text { talented employees at Egyptian travel } \\
\text { agents. }\end{array}$ & Accepted \\
\hline $\begin{array}{l}\text { Hypothesis 6: JE mediates the relationship } \\
\text { between HPWPs and creative performance } \\
\text { at the Egyptian travel agents. }\end{array}$ & Accepted \\
\hline $\begin{array}{l}\text { Hypothesis 7: JE mediates the relationship } \\
\text { between HPWPs and the retention of } \\
\text { talented employees at the Egyptian travel } \\
\text { agents }\end{array}$ & Accepted \\
\hline
\end{tabular}

\section{Discussion and conclusion}

The aim of this study is to develop and investigate a model that examines the mediating role of job embeddedness in the relationships among high-performance work practices, creative performance and talented employee retention at the Egyptian travel agents.

The results supported the proposed model and showed that High-Performance Work Practices (HPWPs) significantly and positively affected creative performance $(\mathrm{CP})$ and talent retention (TRT) through job embeddedness (JE). The following sub-sections discuss the results in details.

HPWPs affect significantly and positively JE among employees at Egyptian travel agents. This result is in line with some previous studies, such as, the recent study of Asfar et al. (2018) which concluded that HPWPs have a significant and positive relationship with JE. Additionally, Karatepe and Vatankhah (2014) stated that HPWPs enhance JE. Vatankhah (2013) mentioned that HPWPs indicators (empowerment, training, job security, rewards, teamwork. Selective staffing, career opportunities) raise the level of JE among employees.

Moreover, the results revealed that HPWPs have a significant and positive impact on $\mathrm{CP}$, which means that HPWPs greatly enhance $\mathrm{CP}$ within the organization. This result is consistent with many previous studies. Karatepe and Vatankhah (2014) and Karatepe et al. (2014) mentioned that HPWPs affect positively CP. Also, Kang (2015) argued that HPWPs have a positive effect on employees' creativity and organizational innovation performance. Chiang et al. (2015) and Tang et al. (2017) pointed out that there is a significant and positive relationship between HPWPs and employees' creativity. Similarly, Athwaria 
(2016) proved that HPWPs affect significantly the creativity of employees. Finally, Jeong and Shin (2017) concluded that HPWPs greatly enhance organization creativity.

Additionally, the results illustrated that HPWPs influence significantly and positively TRT. This result is in line with the study of Combs et al. (2006), which depicted that HPWPs reduce employees' turnover intention. Kerr et al. (2007); Partel and Conklin (2012) and Pittino et al. (2016) added that HPWPs positively influence the retention of valuable employees. The findings of Rubel and Hung (2013) showed that HPWPs play an outstanding role in maintaining and utilizing talented and skilled employees. Vatankhah (2013) determined that HPWPs help retaining talented employees and reducing turnover. Furthermore, Joy (2016) clarified that the implementing HPWPs decreases turnover rates in the organization. As well as, Asfar et al. (2018) highlighted that teamwork, selective staffing, rewards, and career opportunities help maintaining the high-performance employees.

Among the important results, the study proved that JE has a positive influence on CP. This result means that job embeddedness enhances and raises creative performance. This result is in line with the findings of $\mathrm{Ng}$ and Feldman (2010), which illustrated that JE raises motivation of employees greatly to create, exchange and implement innovative ideas within the organization. Karatepe (2016) said that JE influences positively performance generally and creative performance particularly. As well as, Liu (2018) pointed out that JE has a positive effect on creative performance. But this result is not in line with the study of Greene (2012), which revealed that there is no relationship between JE and CP.

The results also clarified that JE has a significant and positive effect on TRT. This result is consistent with the study of Young
(2012) and Young et al. (2013), which stated that JE has a great influence on intent to stay. Similarly, Zhang et al. (2012) demonstrated that high embedded employees are more likely to stay in their organization rather than those who less embedded. Halvorsen (2014) commented that JE is considered a predictive factor for employee intention to leave. Moreover, Nicholas et al. (2016) confirmed that JE has a significant and positive impact on turnover intention. Yam et al. (2018) depicted that JE plays a role in explaining employees intention to stay in the organization.

Finally, the results concluded that job embeddedness plays a partial mediating role in the relationship between high-performance work practices, creative performance, and talented retention at the Egyptian travel agents.

\section{Implications and further research}

According to the findings of the study; the rewards was the least indicator of the Highperformance work practices. Therefore, travel agents should set a fair and incentive reward policy related to the rate of employees' efforts. Travel agents should also enhance feelings of job security for employees to guarantee high job stability, which lead to increase their engagement and loyalty. Moreover, these agents should pay more attention to the implementation of training programs focused on achieving outstanding customer service. In addition, to achieve a high level of job embeddedness among employees and maintain and attract talented; these agents should improve the quality of work life, achieve organizational justice, apply a participatory leadership style, build trust and strong relationships between management and employees. As well as the need for an effective policy to attract and motivate talent and keep them within the agent. 
In terms of further researches, this study examined the mediating role of job embeddedness in the relationships among high-performance work practices, creative performance and talented employee retention in the Egyptian travel agents. Further studies may discuss other intermediate variables such as the applicable leadership style, ambiguity of functional role, strategic intelligence, organizational anomie and organizational. The study also focused on the employees of the travel agents; further studies may focus on the managers of these agents to identify the impacts of HPWPs on several variables such as organizational agility, organizational effectiveness, job satisfaction, organizational identification, competitive advantage ... and other variables related to the efficiency of the travel agents' performance.

\section{References:}

- Afsar, B., Shahjehan, A., \& Shah, S. (2018), 'Frontline employees' high-performance work practices, trust in supervisor, jobembeddedness and turnover intentions in hospitality industry', International Journal of Contemporary Hospitality Management, 30(3), pp. 1436-1452.

- Alferaih, A., Sarwar, S., \& Eid, A. (2018), 'Talent turnover and retention research: The case of tourism sector organisations in Saudi Arabia'. In Evidence-based HRM: A Global Forum for Empirical Scholarship. Emerald Publishing Limited. retrieved from:https://www.emeraldinsight.com/doi/abs/ 10.1108/EBHRM-06-2017-0035 at November $\underline{2018}$.

- Asmawi, A., \& Chew, K. (2017), 'Implementation of high-performance work practices (HPWP) in R\&D organizations: Empirical evidence from Malaysia'. In Industrial Engineering and Engineering Management (IEEM), December 2017 IEEE International Conference on (pp. 279-283). IEEE.

- $\quad$ Athwaria, S. (2016), 'High- Performance Work Practices' and Employees' Creativity: Testing the relationship', International Journal of Human Resource \& Industrial Research, 3(3), pp. 79-92.

- Boselie, P., Dietz, G. \& Boon, C. (2005), 'Commonalities and contradictions in HRM and performance research', Human Resource Management Journal, 15(3), pp. 67-94.

- Carlson, D., Grzywacz, J., \& Zivnuska, S. (2009), 'Is work-family balance more than conflict and enrichment?', Human relations, 62(10), pp. 1459-1486.

- Chan, F., Lee, G., Lee, E., Kubota, C., \& Allen, C. (2007), 'Structural equation modeling in rehabilitation counseling research', Rehabilitation Counseling Bulletin, 51(1), pp. 44-57.

- Chiang, F., \& Birtch, T. (2011), 'Reward climate and its impact on service quality orientation and employee attitudes', International Journal of Hospitality Management, 30(1), pp. 3-9.

- Chiang, Y., Hsu, C., \& Shih, H. (2015), 'Experienced high-performance work system, extroversion personality, and creativity performance', Asia Pacific Journal of Management, 32(2), pp. 531-549.

- Cho, S., Woods, R., Jang, S., \& Erdem, M. (2006), 'Measuring the impact of human resource management practices on hospitality firms' performances', International Journal of Hospitality Management, 25(2), pp. 262-277.

- Combs, J., Liu, Y., Hall, A., \& Ketchen, D. (2006), 'How much do high-performance workp ractices matter? A meta-analysis of their effects on organizational performance', Personnel Psychology, 59(3), pp. 501-528.

- Crossley, C., Bennett, R., Jex, S., \& Burnfield, J. (2007), 'Development of a global measure of job embeddedness and integration into a traditional model of voluntary turnover', Journal of Applied Psychology,92(4), pp. 1031-1042.

- Datta, D., Guthrie, J., \& Wright, P. (2005), 'Human resource management and labor productivity: Does industry matter?', Academy of Management Journal, 48 (1), pp. 135-145.

- Davidson, M., McPhail, R., \& Barry, S. (2011), 'Hospitality HRM: Past, Present and the Future', International Journal of Contemporary Hospitality Management, 23(4), pp. 498-516. 
- Frank, F., Finnegan, R., \& Taylor, C. (2004), 'The race for talent: Retaining and engaging workers in the 21st century', Human Resource Planning, 27(3), pp. 12-25.

- Fu, N., Flood, P., Bosak, J., Morris, T. \& O'Regan, P. (2015), 'How do high performance work systems influence organizational innovation in professional service firms?', Employee Relations, 37(2), pp. 209-231.

- $\quad$ Gefer, D., Straub, D., \& Boudreau, M. (2000), 'Structural equation modeling and regression: Guidelines for research practice', Communications of the association for information systems, 4(1), pp. 1-70.

- Govaerts, N., Kyndt, E., Dochy, F., \& Baert, H. (2011), 'Influence of learning and working climate on the retention of talented employees', Journal of Workplace Learning, 23(1), pp. 35-55.

- Greene, J. (2012), 'Job Embeddedness: Do the Interaction Effects of Attitude, Personality, and Exchange Relationships Detract from Performance?', ( unpublished Doctoral dissertation), Coles College of Business, Kennesaw State University.

- Grobler, P., \& Diedericks, H. (2009), 'Talent management: An empirical study of selected South African hotel groups', Southern African Business Review, 13(3), pp. 1-27.

- Hair, J., Anderson, R., Tatham, R., \& Black, W. (1992), 'Multivariate Data Analysis, with Readings', ( $3^{\text {rd }}$ edition), Macmillan, New York, NY.

- $\quad$ Hair, J., Black, W., Babin, B., \& Anderson, R. (2010), 'Multivariate Data Analysis', ( $7^{\text {th }}$ edition), Pearson prentice Hall.

- Hair, J., Sarstedt, M., Hopkins, L., \& Kuppelwieser, V. (2014), 'Partial least squares structural equation modeling (PLS-SEM) An emerging tool in business research', European Business Review, 26(2), pp. 106-121.

- Halbesleben, J., \& Wheeler, A. (2008), 'The relative roles of engagement and embeddedness in predicting job performance and intention to leave', Work and Stress, 22(3), pp. 242-256.

- Halvorsen, B. (2015), 'Factors that Affect Employee Retention: A Job Embeddedness Account of Migrant Turnover Intentions and Job Search Activities', (Unpublished Doctoral dissertation), University of South Australia.
- Harris, K., Wheeler, A., \& Kacmar, K. (2011), 'The mediating role of organizational job embeddedness in the LMX-outcomes relationships', The Leadership Quarterly, 22(2), pp. 271-281.

- Hiltrop, J. (1999), 'The quest for the best: Human resource practices to attract and retain talent', European Management Journal, 17(4), pp. 422-430.

- Holtom, B., \& Inderieden, E. (2006), 'Integrating the unfolding model and job embeddedness model to better understand voluntary turnover', Journal of Managerial Issues, 18(4), pp. 435-452.

- Holtom, B., Mitchell, C., \& Lee, T. (2006), 'Increasing human and social capital by applying job embeddedness theory', Organizational Dynamics, 35(4), pp. 316-331.

- Holtom, B., Burton, J., \& Crossley, C. (2012), 'How negative affectivity moderates the relationship between shocks, embeddedness and worker behaviors', Journal of Vocational Behavior, 80(2), pp. 434-443.

- Hu, L., \& Bentler, P. (1999), 'Cutoff criteria for fit indexes in covariance structure analysis: Conventional criteria versus new alternatives', Structural equation modeling: a multidisciplinary journal, 6(1), pp. 1-55.

- Humaid, H. (2018), 'Talent Management and Organizational Performance: The Mediating Role of Employee Engagement - A Case Study Bank of Palestine in the Gaza Strip', (Unpublished Master Thesis), Faculty of Commerce, The Islamic University-Gaza.

- Jeong, I., \& Shin, S. (2017), 'Highperformance work practices and organizational creativity during organizational change: A collective learning perspective', Journal of Management, $\mathrm{xx}(\mathrm{x})$, pp. 1-17.

- Jiang, K., Liu, D., McKay, P., Lee, T., \& Mitchell, T. (2012), 'When and how is job embeddedness predictive of turnover? A metaanalytic investigation', Journal of Applied Psychology, 97(5), pp. 1077-1096.

- Joy, M. (2016), 'A study on the impact of highperformance work systems on employee withdrawal behaviors in information technology industry', EPRA International Journal of Economic and Business Review, 4(7), pp. 2349-0187.

- Kang, S. (2015), 'Exploring the link between high performance work systems and 
innovation', (MSc dissertation), Rutgers University, New Brunswick, New Jersey.

- Karatepe, O., \& Karadas, G. (2012), 'The effect of management commitment to service quality on job embeddedness and performance outcomes', Journal of Business Economics and Management, 13(4), pp. 614-636.

- $\quad$ Karatepe, O. (2013a), 'High-performance work practices, work social support and their effects on job embeddedness and turnover intentions', International Journal of Contemporary Hospitality Management, 25(6), pp. 903-921.

- Karatepe, O. (2013b), 'Perceptions of Organizational Politics and Hotel Employee Outcomes: The Mediating Role of Work Engagement', International Journal of Contemporary Hospitality Management, 25(1), pp. 82-104.

- Karatepe, O. (2013c), 'The effects of work overload and work-family conflict on job embeddedness and job performance: The mediation of emotional exhaustion', International Journal of Contemporary Hospitality Management, 25(4), pp. 614-634.

- Karatepe, O., Baradarani, S., Olya, H., Ilkhanizadeh, S., \& Raoofi, A. (2014), 'The effects of high-performance work practices on critical performance outcomes: Evidence from the hotel industry', European Journal of Tourism, Hospitality and Recreation, 5(3), pp. 49-67.

- Karatepe, O.,\& Vatankhah, S. (2014), 'The effects of high-performance work practices and job embeddedness on flight attendants' performance outcomes', Journal of Air Transport Management, 37, pp. 27-35.

- $\quad$ Karatepe, O. (2016), 'Does job embeddedness mediate the effects of coworker and family support on creative performance? An empirical study in the hotel industry', Journal of Human Resources in Hospitality \& Tourism, 15(2), pp. 119-132.

- $\quad$ Kellett, J., Humphrey, R., \& Sleeth, R. (2009), 'Career Development, Collective Efficacy, and Individual Task Performance', Career Development International, 14(6), pp. 534-546.

- Kerr, G., Way, S., \& Thacker, J. (2007), 'Performance, HR practices and the HR manager in small entrepreneurial firms', Journal of Small Business and Entrepreneurship, 20(1), pp. 55-68.
- Khan, M., Safwan, N., \& Ahmad, A. (2011), 'Modeling link between internal service quality in human resources management and employee's retention: A case of Pakistani privatized and public sector banks', African Journal of Business Management, 5(3), pp. 949-959.

- Khorakian, A., Nosrati, S., \& Eslami, G. (2018), 'Conflict at work, job embeddedness, and their effects on intention to quit among women employed in travel agencies: Evidence from a religious city in a developing country', International Journal of Tourism Research, 20(2), pp. 215-224.

- Kim, N. (2014), 'Employee turnover intention among newcomers in travel industry', International Journal of Tourism Research, 16(1), pp. 56-64.

- $\quad$ Lee, T., Mitchell, T., Sablynski, C., Burton, J., \& Holtom, B. (2004), 'The effects of job embeddedness on organizational citizenship, job performance, volitional absences, and voluntary turnover', Academy of Management Journal, 47(5), pp. 711-722.

- $\quad$ Lee, T., Burch, T., \& Mitchell, T. (2014), 'The story of why we stay: A review of job embeddedness', Annual Review of Organizational Psychology and Organizational Behavior., 1(1), pp. 199-216.

- Liang, S., \& Hsieh, A. (2005), 'Individual's Perception of Career Development and Job Burnout among Flight Attendants in Taiwan', The International Journal of Aviation Psychology, 15(2), pp. 119-134.

- $\quad$ Lin, J., Wong, J., \& Ho, C. (2013), 'Promoting frontline employees' quality of life: Leisure benefit systems and work-to-leisure conflicts', Tourism Management, 36, pp. 178-187.

- Liu, R. (2018), 'The impact of job embeddedness on employee's performancethe regulation study of relational embeddedness', Journal of Human Resource and Sustainability Studies, 6, pp. 8-23.

- Macky, K., \& Boxall, P. (2007), 'The relationship between high-performance work practices and employee attitudes: An investigation of additive and interaction effects', International Journal of Human Resource Management, 18(4), pp. 537-567.

- Maślanka-Wieczorek, B. (2014), 'Talent management and high-performance work 
system', Journal of International Studies, 7(1), pp. 102-108.

- Mazzei, M., Flynn, C., \& Hayne, J. (2016), 'Moving beyond initial success: Promoting innovation in small businesses through highperformance work practices', Business Horizons, 59(1), pp. 51-60.

- $\quad$ Mitchell T., Holtom, B., Lee, T., Sablynski, C., \& Erez, M. (2001), 'Why People Stay: Using Job Embeddedness to Predict Voluntary Turnover', Academy of Management Journal, 44(6), pp. 1102-1121.

- $\quad$ Moncarz, E., Zhao, J., \& Kay, C. (2009), ‘An exploratory study of US lodging properties' organizational practices on employee turnover and retention', International Journal of Contemporary Hospitality Management, 21(4), pp. 437-458.

- Murphy, K., Torres, E., Ingram, W., \& Hutchinson, J. (2018), 'A review of highperformance work practices (HPWPs) literature and recommendations for future research in the hospitality industry', International Journal of Contemporary Hospitality Management, 30(1), pp. 365-388.

- Nafei, W. (2014), 'The effects of job embeddedness on organizational cynicism and employee performance: A study on Sadat City University', International Journal of Business Administration, 6(1), p. 8.

- $\quad \mathrm{Ng}, \mathrm{T} .$, \& Feldman, D. (2010), 'The impact of job embeddedness on innovation-related behaviors', Human Resource Management, 49(6), pp. 1067-1087.

- Nicholas, A., Mensah, A., \& Owusu, N. (2016), 'Stay or Leave? Using job embeddedness to explain turn over intention among hotel staff in Ghana', Journal of Management Research, 8(3), pp. 123-139.

- Patel, P., \& Conklin, B. (2012), 'Perceived labor productivity in small firms: The effects of high-performance work systems and group culture through employee retention', Entrepreneurship Theory and Practice,36(2), pp. 205-235.

- Pittino, D., Visintin, F., Lenger, T., \& Sternad, D. (2016), 'Are high performance work practices really necessary in family SMEs? An analysis of the impact on employee retention', Journal of Family Business Strategy, 7(2), pp. 75-89.
- Poulston, J. (2008), 'Hospitality workplace problems and poor training: A close relationship', International Journal of Contemporary Hospitality Management, 20, pp. 412-427.

- $\quad$ Ramesh, A., \& Gelfand, M. (2010), 'Will they stay or will they go? The role of job embeddedness in predicting turnover in individualistic and collectivistic cultures', Journal of Applied Psychology, 95(5), pp. 807823.

- Ramlall, S. (2004), 'A review of employee motivation theories and their implications for employee retention within organizations', Journal of American Academy of Business, 5(1/2), pp. 52-63.

- $\quad$ Robinson, R., Kralj, A., Solnet, D., Goh, E., \& Callan, V. (2014), 'Thinking job embeddedness not turnover: Towards a better understanding of frontline hotel worker retention', International Journal of Hospitality Management, 36, pp. 101-109.

- Rubel, M., \& Hung, D. (2013), 'High performance work practice (HPWP) and employee turnover intention in South Asian countries', International Business Management, 7(6), pp. 452-462.

- Schumacker, R., \& Lomax, R. (2010), 'Structural Equation Modeling', (3 ${ }^{\text {rd }}$ edition), Routledge, New York.

- Sofijanova, E., \& Zabijakin-Chatleska, V. (2013), 'High performance work practices and organizational performance: an analysis of the macedonian food and beverage industry'. In: XI International Scientific Conference "Management and Engineering '13", 23-26 June 2013, Sozopol, Bulgaria. Retrieved from http://eprints.ugd.edu.mk/6959/

- $\quad$ Sun, T., Zhao, X., Yang, L., \& Fan, L. (2012), 'The impact of psychological capital on job embeddedness and job performance among nurses: A structural equation approach', Journal of advanced nursing, 68(1), pp. 69-79.

- Tabachnick, B., \& Fidell, L. (2010), 'Using Multivariate Statistics', (4 ${ }^{\text {th }}$ edition), Boston Allyn and Bacon.

- Tang, T., \& Tang, Y. (2012), 'Promoting service-oriented organizational citizenship behaviors in hotels: The role of highperformance human resource practices and organizational social climates', International 
Journal of Hospitality Management, 31, pp. 885-895.

- Tang, G., Yu, B., Cooke, F., \& Chen, Y. (2017), 'High-performance work system and employee creativity: The roles of perceived organizational support and devolved management', Personnel Review, 46(7), pp. 1318-1334.

- Vatankhah, S. (2013), 'Does Job Embeddedness Mediate the Effects of HighPerformance Work Practices on Turnover Intentions? A Study in the Airline Industry', (MSc dissertation), Eastern Mediterranean University (EMU). Gazimağusa, North Cyprus.

- Wallis, T., Winternitz, G., \& Birt, M. (2004), 'Talent retention in a changing workplace: An investigation of variables considered important to South African talent', South African Journal of Business Management, 35(2), pp. 25-31.

- Wang, G., \& Netemeyer, R. (2004), 'Salesperson creative performance: conceptualization, measurement, and nomological validity', Journal of Business Research, 57(8), pp. 805-812.

- Watson, J. (2018), 'Job Embeddedness May Hold the Key to the Retention of Novice Talent in Schools', Educational Leadership and Administration: Teaching and Program Development, 29(1), pp. 26-43.

- Wheeler, A., Harris, K., \& Harvey, P. (2010), 'Moderating and mediating the HRM effectiveness - intent to turnover relationship: The roles of supervisors and job embeddedness', Journal of Managerial Issues, pp. 182-196.

- Wirtz, J., Heracleous, L., \& Pangarkar, N. (2008), 'Managing Human Resources for Service Excellence and Cost Effectiveness at Singapore Airlines', Managing Service Quality, 18(1), pp. 4-19.

- Yam, L., Raybould, M., \& Gordon, R. (2018), 'Employment stability and retention in the hospitality industry: Exploring the role of job embeddedness', Journal of Human Resources in Hospitality \& Tourism, pp. 1-20.

- Young, J. (2012), 'Job embeddedness theory: can it help explain employee retention?', (unpublished Doctoral dissertation), University of Louisville, Louisville, KY.

- $\quad$ Young, J., Stone, J., Aliaga, O., \& Shuck, B. (2013), 'Job Embeddedness Theory: Can It Help Explain Employee Retention among
Extension Agents?', Journal of Extension, 51(4), pp. 1-11.

- Zacharatos, A., Barling, J., \& Iverson, R. (2005), 'High-performance work systems and occupational safety', Journal of applied psychology, 90 (1), pp. 77-93.

- Zhang, M., Fried, D., \& Griffeth, R. (2012), ‘A review of job embeddedness: Conceptual, measurement issues, and directions for future research', Human Resource Management Review, 22(3), pp. 220-231.

- Zhang, Y. (2013), 'Research of employee retention on job embeddedness perspective. In Proceedings of the 2013 International Conference on Advances in Social Science, Humanities, and Management (Vol. 15, pp.2025).

- Zhang, J., Akhtar, M., Bal, P., Zhang, Y., \& Talat, U. (2018), 'How Do High-Performance Work Systems Affect Individual Outcomes: A Multilevel Perspective?', Frontiers in psychology, 9, p. 586.

- Zhou, J., \& Shalley, C. (2003), 'Research on employee creativity: A critical review and directions for future research', Research in personnel and human resources management, 22, pp. 165-218. 